\title{
ORIGINAL
}

\section{Structural Identification of Minor Phosphoinositol Lipids in Sulfolobus acidocaldarius N-8}

\author{
Akihiko SUGAI*1, Ikuko UDA*1, Kazuo Kon*2, Susumu ANDO*2 \\ Yuko H. ITOH*3, and Toshihiro ITOH*1 \\ *1 Division of Chemistry, Center of Liberal Arts and Sciences, Kitasato University \\ (1-15-1 Kitasato, Sagamihara-shi, Kanagawa-ken, =228) \\ *2 Department of Membrane Biochemistry, Tokyo Metropolitan Institute of Gerontology \\ (Sakae-cho 35-2, Itabashi-ku, Tokyo, T173) \\ *3 Department of Bioengineering, Faculty of Engineering, Soka University \\ (1-236 Tangi-cho, Hachioji-shi, Tokyo, T192)
}

\begin{abstract}
Examination was made of the dialkyl-diether-type (archaeol) and trialkyl-tetraethertype (caldarchaeol-trialkyl-type) lipids, low concentrated components of lipids from Sulfolobus acidocaldarius $\mathrm{N}-8$. PL-X as intact dialkyl-diether-type lipid, and PL-Y and PL-Z as intact trialkyl-tetraethertype lipids were newly found. The structure of PL-X was a diether analog of phosphatidyl inositol, and both PL-Y and PL-Z were also phosphoinositol lipids, in the former, one inositol-monophosphate was linked to glycerol on one side of the core lipid, and in the latter, inositol-monophosphates were linked to glycerols on both sides of the core. There may possibly be a pathway in which tetraether type lipids are biosynthesized through PL-Y, following the production of $\mathrm{PL}-\mathrm{Z}$ from two molecules of PL-X. PL-X content constituted about $5 \%$ the total lipids ; PL-Y and PL-Z were present as less than $1 \%$ total lipids in $S$. acidocaldarius $\mathrm{N}-8$.
\end{abstract}

Key words : archaebacteria, lipid, phospholipid, Sulfolobus acidocaldarius

\section{Introduction}

The extremely thermoacidophilic archaebacteria, Sulfolobus acidocaldarius N-8 has been shown to contain lipids of varying complexity which afford, on hydrolysis, two classes of isopranoid ether core lipids, diether and tetraethers ${ }^{1)}$. Those core lipids were named archaeol and caldarchaeol, respectively ${ }^{2}$. The lipids derived from tetraethers, diglycerocaldarchaeol $(\mathrm{DGCOH})$ and calditoglycerocaldarchaeol $(\mathrm{CGCOH})$ were already identified, however, glyceroarchaeol $(\mathrm{GAOH})$ and the trialkyl type of DGCOH (DGCOH-T) were known only to exist in the core lipid of Sulfolobus ${ }^{3), 4)}$. Recently, it has become important to determine the structures of the intact lipids derived from GAOH and DGCOH-T, because these lipids are considered as a precursor or intermediate products of tetraetherlipids derived from DGCOH or $\mathrm{CGCOH}^{2)}$. In this paper, the structures of the lipids composing the GAOH and DGCOH-T cores of $S$. acidocaldarius $\mathrm{N}-8$ which was isolated from the hot-acidic spring of Noboribetsu in Japan were investigated.

\section{Experiments}

\subsection{Chemicals}

Chloroform and methanol were of reagent grade and were freshly distilled before use. Other organic and inorganic reagents, of the highest analytical grade commercially availabel,

Corresponding author : Akihiko SUGAI 
were used without further purification.

\subsection{Growth of the Bacterium and Extraction of Lipids}

S. acidocaldarius $\mathrm{N}-8$, an extremely thermoacidophilic archaebacterium isolated from the acidic hot spring of Noboribetsu in Japan, was grown at $75^{\circ} \mathrm{C}$ as described previously ${ }^{1)}$. Total lipids were extracted from stationary phase cells with neutral solvents as described in a previous report ${ }^{5}$.

\subsection{Purification of lipids}

Total lipids $(200 \mathrm{mg}$ ) were fractionated on a column(I.D. $3 \mathrm{~cm} \times 20 \mathrm{~cm}$ ) of DEAE-Sephadex A-25 (Phalmacia, acetate form) into neutral lipids and acidic lipids. After the total lipids were applied onto the column, neutral lipids were eluted with $300 \mathrm{~mL}$ of chloroform/methanol/water ( $3: 4: 1$, by vol), and acidic lipids were eluted with $300 \mathrm{~mL}$ of chloroform/methanol/0.8 M sodium acetate solution (3:4:1, by vol).

Separation of the individual lipids from the acidic lipid fraction was performed using a silica gel column (I. D. $1 \mathrm{~cm} \times 30 \mathrm{~cm}$, Iatrobeads $6 \mathrm{RS}-8060$, Iatron, Japan) as follows. The column was eluted with a linear gradient from chloroform/methanol $(8: 2$, vol/vol) to chloroform/methanol/water (40:160:10, by vol). Further purifications were performed using a prepacked reversed-phase column (SEP-PAK $\mathrm{C}_{18}$ cartridges, Millipore, USA). The fractions containing the intact lipids of GAOH or DGCOH-T were dissolved in $1.6 \mathrm{~mL}$ of chloroform/ methanol/water ( $1: 6: 1$, by vol), and applied onto each column. After washed with $2 \mathrm{~mL}$ of the same solvent, fractions were eluted with $3 \mathrm{~mL}$ of chloroform/methanol/water $(2: 6: 1$, by vol) and with $3 \mathrm{~mL}$ of chloroform/methanol/water $(3: 6: 1$, by vol). The final purification of the lipids was performed by preparative TLC.

\section{$2 \cdot 4$ Thin-layer chromatography}

Thin-layer chromatography of the intact lipids were carried out on precoated silica gel 60 plates (HPTLC, Art. 5641, Merck, Germany) for both analytical and preparative separations. The plates were activated at $120^{\circ} \mathrm{C}$ for $2 \mathrm{~h}$ after treatment with methanol solution containing $3 \% \mathrm{H}_{3} \mathrm{BO}_{3}$, and developed in solvent system A consisting of chloroform/methanol/ $0.2 \% \mathrm{CaCl}_{2}$ (55:45:7, by vol). For the separation of the core lipids, the plates, without any treatment, were developed using the following solvent : B, hexane/ether/acetic acid (30:20: 1 , by vol) or C, chloroform/ethanol ( $9: 1, \mathrm{vol} / \mathrm{vol})$. The phospholipids were visualized after spraying the chromatogram with Dittmer reagent ${ }^{6)}$, then charred at $140^{\circ} \mathrm{C}$ for 15 min to detect all of the lipids. The lipid contents were estimated by a densitmeter (Dual-Wavelength Chromato Scanner CS-930, Shimadzu) on TLC which was charred at $140^{\circ} \mathrm{C}$ for 15 min after spraying with $50 \% \mathrm{H}_{2} \mathrm{SO}_{4}$.

Inositol-monophosphate was developed on precoated HPTLC cellulose plates (Art. 5787, Merck, Germany) in the solvent system, $n$-propanol/1 $\mathrm{M} \mathrm{NH}_{4} \mathrm{OH}(2: 1$, vol/vol). Inositol phosphate was visualized under a UV lamp after spraying the chromatogram with HanesIsherwood reagent ${ }^{7}$.

\subsection{Analytical methods and chemical procedures}

Phosphorus was measured by a previous method ${ }^{8}$. Acid methanolysis was performed with $5 \% \mathrm{HCl}-$ methanol at $100^{\circ} \mathrm{C}$ for $2 \mathrm{~h}$. The preparation of hydrocarbons of GAOH and CGCOH-T were performed with HI degradation followed by zinc-acetic acid reduction as previously described $^{9)}$. Acid hydrolysis was carried out in $2 \mathrm{M} \mathrm{HCl}$ at $120^{\circ} \mathrm{C}$ for $40 \mathrm{~h}$. Inositol phosphate of the lipids was prepared by alkali hydrolysis with $2 \mathrm{M} \mathrm{KOH}$ at $100^{\circ} \mathrm{C}$ for $1 \mathrm{~h}$ according to Pizer \& Ballou ${ }^{10)}$. Trimethylsilylation of inositol was performed with a mixture of pyridine/ 1,1,1,3,3,3-hexamethyldisilazane/trimethylchlorosilane $\left(5: 1: 1\right.$, by vol) at $100^{\circ} \mathrm{C}$ for $40 \mathrm{~min}$.

\subsection{Enzymatic procedure}

The enzyme reactions of the phosphoinositol lipids were carried out with monophosphatidylinositol phosphodiesterase (PI-specific phospholipase C, from Bacillus thuringiensis, Funakoshi, Japan) as follows ; $100 \mu \mathrm{g}$ of these lipids were dissolved in $100 \mu \mathrm{L}$ of $0.8 \%$ sodium 
desoxycholate solution and allowed to stand in a sonicator until suspended, then $350 \mu \mathrm{L}$ of $0.1 \mathrm{M}$ Tris- $\mathrm{HCl}$ buffer and 0.13 unit of $\mathrm{PI}$-specific phospholipase $\mathrm{C}$ were added. The mixture was allowed to stand at $37^{\circ} \mathrm{C}$ for $12 \mathrm{~h}$. The core lipid was extracted with chloroform from the reaction mixture.

\subsection{Gas-liquid chromatography}

Gas-liquid chromatography was performed on a Hitachi 163 gas chromatograph equipped with flame ionization detectors. Trimethylsilylated inositol was analyzed on a $2 \mathrm{~m}$ glass column (I.D. $3 \mathrm{~mm}$ ) packed with $3 \% \mathrm{OV}-101$ on Chromosorb WAW at $100^{\circ} \mathrm{C}$. The numbers of cyclizations in the isopranoid chain were analyzed by a $1 \mathrm{~m}$ glass column(I.D. $3 \mathrm{~mm}$ )packed with $2 \%$ Dexsil $300 \mathrm{GC}$ on Uniport $\mathrm{HP}$ at a temperature increasing from $100^{\circ} \mathrm{C}$ to $300^{\circ} \mathrm{C}$ at a rate of $15^{\circ} \mathrm{C} / \mathrm{min}$.

\subsection{Physical measurements}

Fast atom bombardment mass (FAB-MS) spectra were measured in the negative ion mode by JMS DX-300 (Japan Electron Optics Laboratory, Japan), and glycerol was used as the matrix.

For NMR spectroscopy, intact lipids were dissolved in DMSO. High resolution ${ }^{1} \mathrm{H}$ NMR spectra were performed at $399.95 \mathrm{Mz}$, at $90^{\circ} \mathrm{C}$ in $5-\mathrm{mm}$ tubes using a Varian XL-400 spectrometer.

\section{Results and Discussion}

In $S$. acidocaldarius $\mathrm{N}-8$, CGCOH contained in $75 \%$ of the total core lipids, and DGCOH, $\mathrm{GAOH}$ and $\mathrm{DGCOH}-\mathrm{T}$ were $15 \%, 5 \%$, and $2 \%$ of the total, respectively. By examination of the distribution of $\mathrm{GAOH}$ and $\mathrm{DGCOH}$ in the neutral and acidic lipids prepared from the total lipids using a DEAE-Sephadex A-25 column, both cores were detected only in the acidic lipid fraction and no GAOH or DGCOH was detected in the neutal lipid fraction on the TLC.

After the acidic lipid fraction was developed on TLC with solvent A, the core lipids of each band on TLC were investigated. The results showed that GAOH was detected from the PL-1 band (diglycerocaldarchaetidylinositol, $R_{f}=0.70$ ). In addition, DGCOH-T was detected from the unidentified band of PL-Y $\left(R_{f}=0.75\right)$ and the GPL-1 band (glucopyranosyl-calditoglycerocaldarchaetidyl-inositol, $\left.R_{f}=0.30\right)$. Although the PL-Y could be easily separated and purified by TLC, the unidentified compounds in which each band of PL-1 and GPL-1 overlapped were unable to be separated using the normal phase TLC. Thus, we called them PL-X and PL-Z instead of each GAOH type lipid and DGCOH-T type lipid.

The acidic lipids were fractionated by the silica gel column and the fractions of PL-Y, PL-1 and GPL-1 were obtained. The PL-1 and GPL-1 were treated with a reversed-phase column cartridge, the PL-X from PL-1 and the PL-Z from GPL-1 could be fractionated. After the lipid of PL-X or PL-Z was eluted with chloroform/methanol/water $(2: 6: 1$, by vol), PL-1 or GPL-1 was eluted with chloroform/methanol/water $(3: 6: 1$, by vol).

$\mathrm{PL}-\mathrm{X}, \mathrm{PL}-\mathrm{Y}$ and $\mathrm{PL}-\mathrm{Z}$ were shown to contain a phosphorus by coloring with Dittmer reagent on TLC. The molar ratios of phosphorus content versus the core lipid for PL-X, PL-Y and PL-Z were $1: 1,1: 1$ and $1: 2$, respectively. Also, myo-inositol was detected from the water soluble components of $\mathrm{PL}-\mathrm{X}, \mathrm{PL}-\mathrm{Y}$ and $\mathrm{PL}-\mathrm{Z}$ that were obtained by heating the intact lipids at $120^{\circ} \mathrm{C}$ for $40 \mathrm{~h}$ with $2 \mathrm{M} \mathrm{HCl}$. The molar ratio of myo-inositol versus the core of the PL-X, PL-Y and PL-Z were same as the ratio of phosphorus. Furthermore, on the cellulose TLC, the spots with the same $R_{f}$ value as myo-inositol-1-monophosphate and myo-inositol-2-monophosphate were detected in the ratio of $9: 1$ from each alkali-hydrolysate of PL-X, PL-Y and PL-Z. The enzymatic reactions by PI-specific phospholipase C of PL-X, PL-Y and PL-Z produced each core lipid and myo-inositol-1,2-cyclicphosphate. From these results, it was found that the products are all phosphoinositol-lipids. Also, by the ${ }^{1} \mathrm{H}-\mathrm{NMR}$, it was shown that the chemical shifts of myo-inositol part of those lipids were 
(A) PL-X

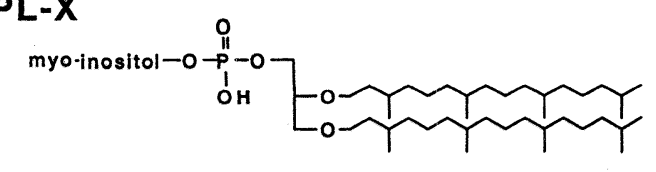

(B)
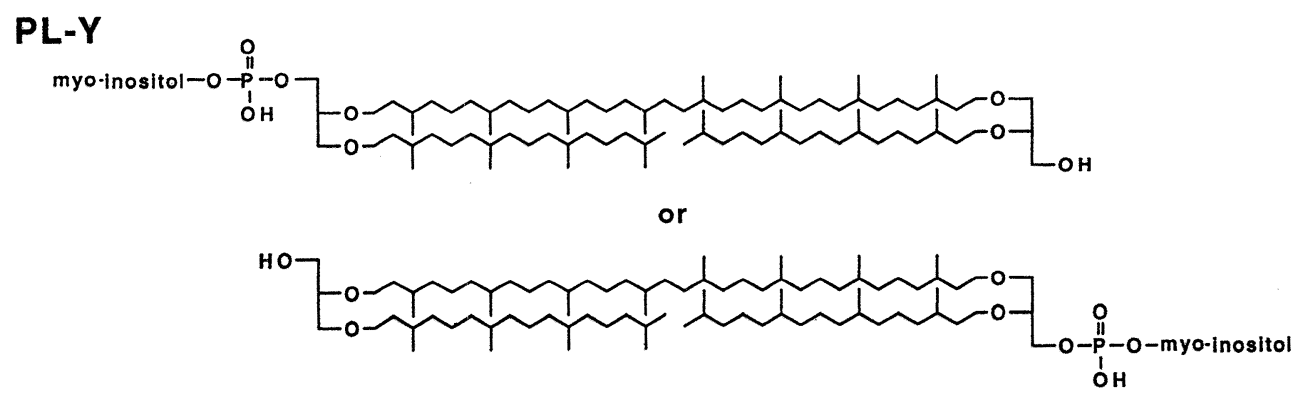

(C)

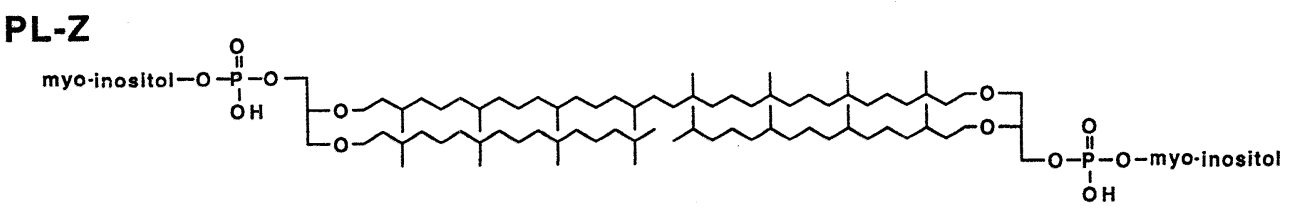

Fig. 1 Proposed Structure (Acyclic Model) of PL-X(a), PL-X (b) and PL-Z (c).

the characteristic chemical shifts of myo-inositol-1-monophosphate. From these facts, we confirmed that the inositol-monophosphate (IP) of PL-X, PL-Y and PL-Z were myo-inositol-1-monophosphate. However, it is necessary to examine whether it is D-form or L-form by the optical rotations, after enough amounts of the lipids will be obtained. It was found that $\mathrm{PL}-\mathrm{X}$ is a lipids group in which inositol-monophosphate was linked with the GAOH core as shown in Fig. 1 (a) and the PL-Y is the one in which IP was linked with one side of the DGCOH-T and was considered to be two typcs of the structure as can be seen in Fig. 1 (b). As it was presumed that two molecules of IP for the lipid core existed in PL-Z, the link conditions were examined. PI-specific phospholipase $\mathrm{C}$ treatment of $\mathrm{PL}-\mathrm{Z}$ produced $\mathrm{PL}-\mathrm{Y}$ for $5 \mathrm{~min}$ reaction, and $\mathrm{DGCOH}-\mathrm{T}$ for $3 \mathrm{~h}$. Only the $\mathrm{DGCOH}-\mathrm{T}$ was produced by methanolysis of fully methylated $\mathrm{PL}-\mathrm{Z}$, however, mono-methyl $\mathrm{DGCOH}-\mathrm{T}$ could not be detected. From these results, it became evident that $\mathrm{PL}-\mathrm{Z}$ is the lipids group in which IP was linked with both sides of the lipids cores as shown in Fig. 1 (c).

FAB-MS spectra for each lipid are shown in Fig. 2. The molecular ion peaks, 894, 1544 and 1786, were detected from PL-X, PL-Y and PL-Z, respectively. These results support the tentative structure we have proposed.

It has been known that a maximum four cyclopentane rings exist in each of the $\mathrm{C}_{40}$ isopranoid chains ${ }^{11), 12}$. Distribution of the lipids which have different cyclization numbers of $\mathrm{C}_{40}$ isopranoid chains in $\mathrm{PL}-\mathrm{Y}, \mathrm{PL}-\mathrm{Z}$ and $\mathrm{PL}-1$ was investigated as shown in Table 1. Both $\mathrm{C}_{40}$ isopranoids of $\mathrm{PL}-\mathrm{Y}$ and $\mathrm{PL}-\mathrm{Z}$ have mostly no ring structure, and the average.cyclization numbers $\left[(\%\right.$ monocyclic $+2 \times \%$ bicyclic $+3 \times \%$ tricyclic $+4 \times \%$ tetracyclic $\left.) \times 10^{-2}\right]$ of the cyclopentane rings in the isopranoid of $\mathrm{PL}-\mathrm{Y}$ was 0.30 and those of $\mathrm{PL}-\mathrm{Z}$ was 0.18 , indicating a more advanced formation of the ring structure for the former than that for the latter. It 
(a)

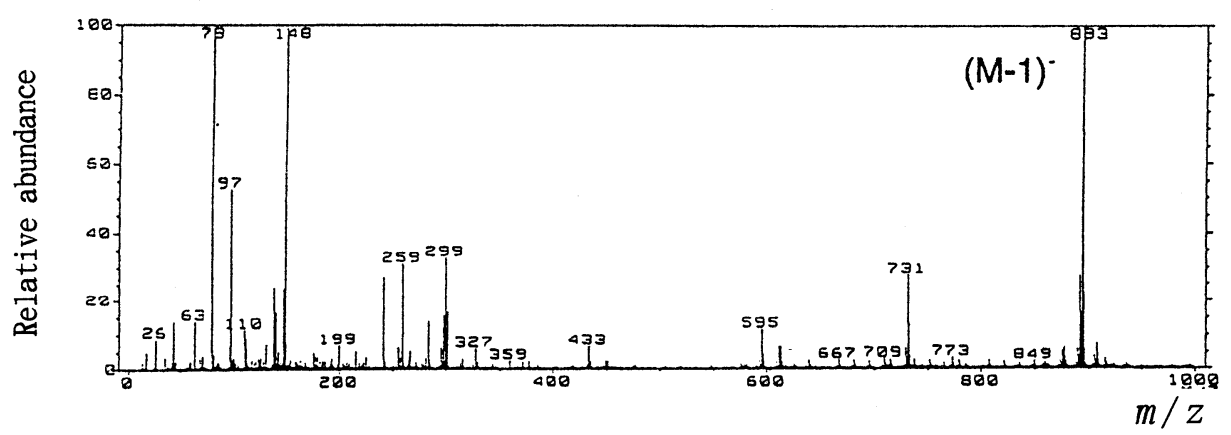

(b)

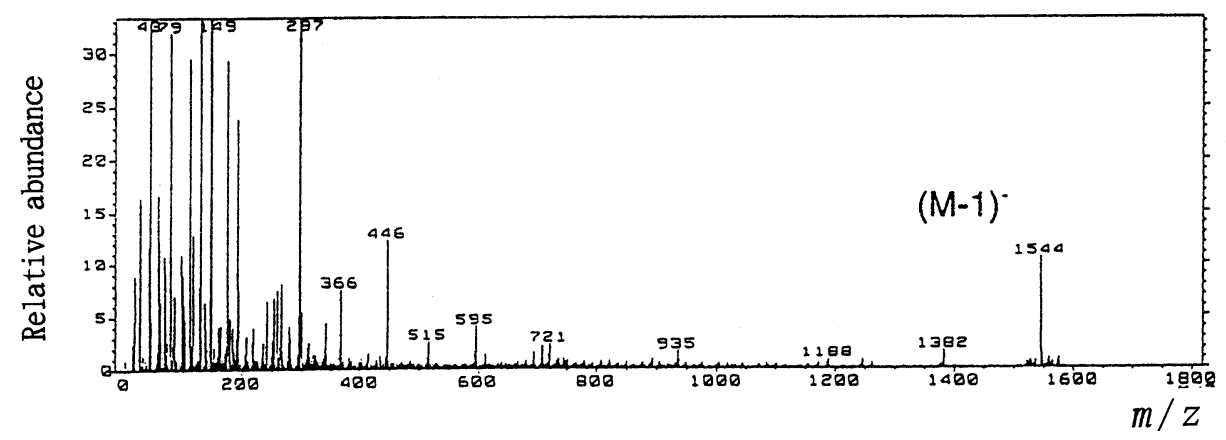

(c)

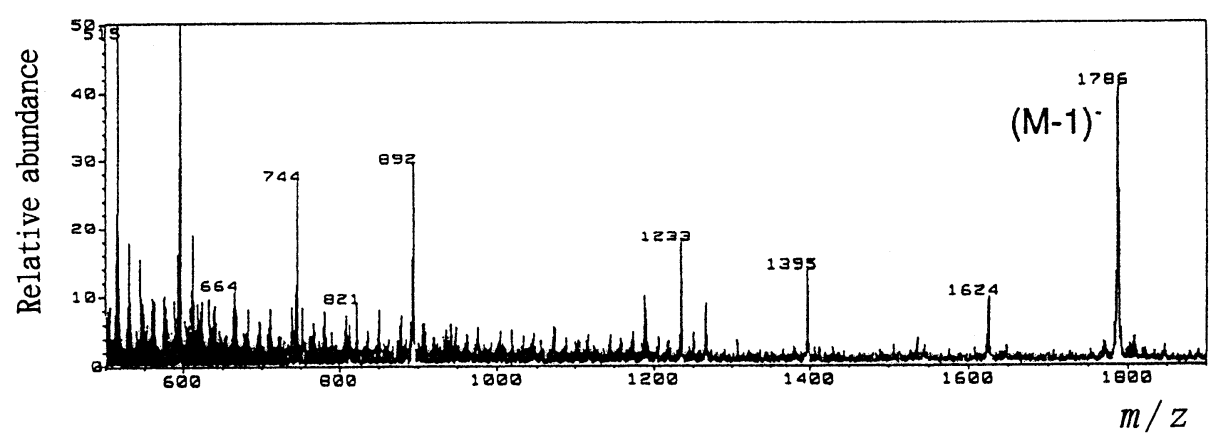

Fig. 2 FAB-MS spectra of PL-X (a), PL-Y (b), and PL-Z (c).

These spectra were obtained in a negative mode with a matrix of glycerol.

Table 1 Cyclization Number(\%)of $\mathrm{C}_{40}$ Isopranoid Chains in $\mathrm{PL}-\mathrm{Y}$, $\mathrm{PL}-\mathrm{Z}$ and $\mathrm{PL}-1$ of $\mathrm{S}$. acidocaldarius $\mathrm{N}-8$ Grown at $75^{\circ} \mathrm{C}$.

\begin{tabular}{|c|c|c|c|}
\hline & $\mathrm{PL}-\mathrm{Y}$ & $\mathrm{PL}-\mathrm{Z}$ & $\mathrm{PL}-1$ \\
\hline $\mathrm{C}_{40} \mathrm{H}_{82} \quad$ (acyclic) & 78.7 & 89.5 & 0.7 \\
\hline $\mathrm{C}_{40} \mathrm{H}_{80} \quad$ (monocyclic) & 12.1 & 2.9 & 3.8 \\
\hline $\mathrm{C}_{40} \mathrm{H}_{78} \quad$ (bicyclic) & 9.1 & 7.6 & 83.4 \\
\hline $\mathrm{C}_{40} \mathrm{H}_{76} \quad$ (tricyclic) & 0.1 & $t^{* * *}$ & 11.8 \\
\hline $\mathrm{C}_{40} \mathrm{H}_{74} \quad$ (tetracyclic) & $-* *$ & - & 0.3 \\
\hline Average cyclization* & 0.30 & 0.18 & 2.07 \\
\hline
\end{tabular}

was shown that a most advanced ring structure of them was detected in the DGCOH inositol phosphate named as PL-1. 


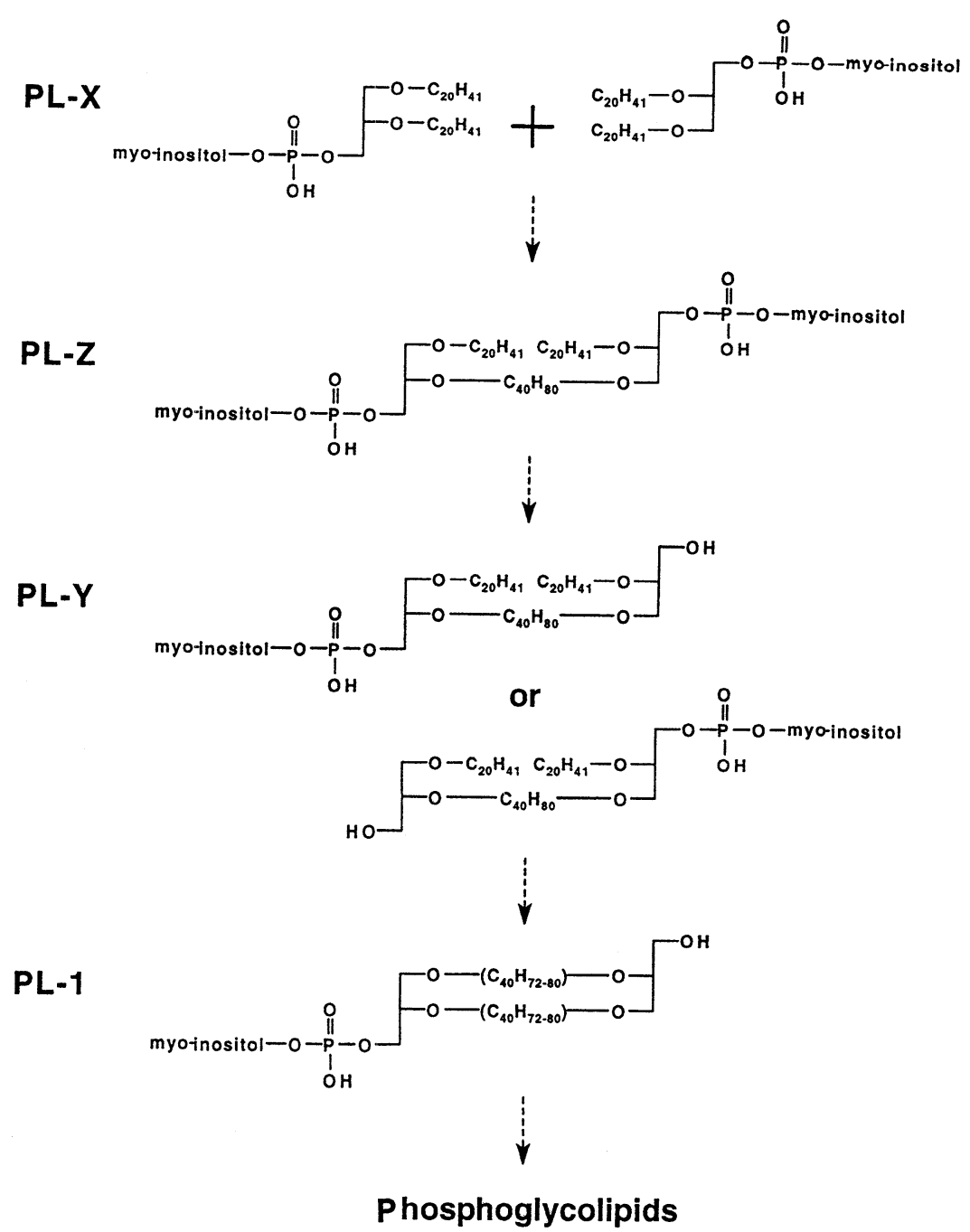

Scheme 1 Presumed Biosynthetic Pathway of PL-1.

The heptad hypothesis ${ }^{13)}$, that is, tetraether type lipids are biosynthesized from one neutral lipid of the diether type and one phospholipid, has been reported in the methanobacterium. In Sulfolobus, no neutral lipids of the diether type were detected. With respect the fact that the tetraether type lipids are biosynthesized from two molecules of acyclic diether type lipids through trialkyl type lipids, then cyclopentane rings are produced in $\mathrm{C}_{40}$ isopranoid chains with numbers adapted to the cultivation temperature, it is presumed that there exists a pathway in which the PL-1 of tetraether type lipids is biosynthesized through the PL-Y, following the production of PL-Z from two molecules of PL-X (Scheme 1). For these reasons, we considered that there exists a biosynthetic pathway for the tetraether type lipids in Sulfolobus being different from that of the methanobacterium.

(Received Sep. 7, 1995 ; Accepted Jan. 23, 1996)

\section{References}

1) N. Kurosawa, A. Sugai, I. Fukuda, T. Itoh, T. Horiuchi, Y. H. Itoh, J. Gen. Appl. Microbiol., 41, 
43 (1995).

2) M. Nishihara, H. Morii, Y. Koga, J. Biochem., 101, 1007 (1987).

3) M. De Rosa, A. Gambacorta, B. Nicolaus, B. Chappe, P. Albrecht, Biochim. Biophys. Acta, 753, 249 (1983).

4) T.A. Langworthy, J.L. Pond, System. Appl. Microbiol., 7, 253 (1986).

5) A. Sugai, R. Sakuma, I. Fukuda, N. Kurosawa, Y.H. Itoh, K. Kon, S. Ando, T. Itoh, Lipids, 30, 339 (1995).

6) J.C. Dittmer, R.L. Lester, J. Lipid Res., 5, 126 (1964).

7) C.S. Hanes, F.A. Isherwood, Nature, 164, 1107 (1949).

8) A. Sugai, R. Sakuma, I. Fukuda, Y. H. Itoh, T. Itoh, J. Jpn. Oil Chem. Soc., 41, 1029, (1992).

9) A. Sugai, I. Uda, N. Kurosawa, A. Shimizu, M. Ikeguchi, Y.H. Itoh, T. Itoh, J. Jpn. Oil Chem. Soc., 44, 1099 (1995).

10) F.L. Pizer, C.E. Ballou, J. Am. Chem. Soc., 81, 915 (1959).

11) M. De Rosa, A. Gambacorta, B. Nicolaus, J.D. Bu'Lock, Phytochemistry, 19, 821 (1980).

12) M. De Rosa, E. Esposito, A. Gambacorta, B, Nicolaus, J.D. Bu'Lock, Phytochemistry, 19, 827 (1980).

13) Y. Koga, M. Nishihara, Seikagaku, 60, 424 (1988). 


\title{
日本油化学会誌本号掲載 論文要旨
}

[総説] シクロデキストリンおょびイオン性ミセルを

用しるキャピラリ一笔気泳動による光学分割

\author{
田中稔 \\ 大阪大学保全科学研究センター（甬565 吹田市山田丘2-4）
}

本総説では, キャピラリー電気泳動を用いる光学分割について概説する。とくに, キャピラリーゾーン電気泳動 とミセル動電クロマトグラフィーの簡単な原理と光学分割への応用について紹介する。泳動電解質溶液中に未修飾 および化学修飾シクロデキストリンをキラルセレクターとして添加し，イオン性エナンチオマーを分離するキャピ ラリーゾーン電気泳動について述へる。この方法のキラル分離は, エナンチオマーの包接錯体形成能の差に基づい ている。化学修飾したシクロデキストリンの置換基の位置と置換度, および電解質溶液への添加剤の光学分割に及 ぼす影響を述べる。キラルミセル相へのエナンチオマーの分配の差に基づいてキラル分離が達成される，キラルな 界面活性剤を用いるミセル動電クロマトグラフィーについて述べる。多用されているイオン性界面活性剤である硫 酸ドデシルナトリウムのミセルとシクロデキストリンを一緒に用いる方法についても簡単に紹介する。

（連絡者：田中 稔）Vo1. 45, №. 4, 319 (1996).

\section{[報文] Sulfolobus acidocaldarius $\mathrm{N}-8$ に於けす る 微量オノシトールリン脂質の構造解析}
須貝昭彦 $* 1$ - 宇田郁子 $* 1$ - 近一夫 $* 2$ ・
安藤進 $* 2$. 伊藤佑子 $* 3$. 伊藤 俊洋 $* 1$
*1 北里大学 ・ 一般教育総合センター
*2 東京都老人総合研究所 ・ 生体膜部門
（更228 神奈川県相模原市北里1-15-1）
（F173 東京都板橋区栄町35-2）
$* 3$ 創価大学・工学部·生物工学科
（テ192 東京都八王子市丹木町1-236）

Sulfolobus acidocaldarius N-8 の微量脂質成分であるジエーテル型脂質とトリアルキルタイプのテトラエーテ ル型脂質の構造について調べ, ジエーテル型脂質のPL-X, トリアルキル型脂質のPL-YとPL-Zの3種類のリン脂質の 構造を明らかにした。PL-Xの構造は, ホスファチジルイノシトールの類似体で, PL-YとPL-Zの両者もイノシトー ルリン脂質であり，前者は脂質骨格の片側のグリセリンにイノシトールリン酸が結合したもの，後者は脂質骨格の 両側のグリセリンにイノシトールリン酸が各々リン酸エステル結合したものであることがわかった。また，2分子 のPL-XからPL-Zが生成し，PL-Yからテトラエーテル型脂質が生合成される経路の存在が推測された。 Sulfolobus acidocaldarius N-8 に於けるPL-Xの含有量は全脂質の約5\%であるが, PL-YとPL-Zは1\%以下であった。

（連絡者：須貝昭彦）Vol. 45, No. 4, 327 (1996).

\footnotetext{
[報文]キャピラリーガスクロマトグラフィーによる

精整保油中のIPA歹びDHAの定量

一合同奉験苏び標準化 -

梶島俊樹 $* 1$ - 青木滋 $* 2$ - 西本ゆかり $* 3$ ・

長谷川栄治 $* 4$. 森好栄子 $* 5$. 永山裕美 $* 6$

*1 日本油脂株式会社 王子工場食品研究所（テ114 東京都北区豊島4-18-11）

*2 日本水産株式会社 中央研究所 （テ192 東京都八王子市北野町559-6)

*3 日本合成化学工業株式会社 中央研究所（再567 大阪府茨木市室山2-13-1）

*4 日本化学飼料株式会社 中央研究所 （宁040 北海道函館市浅野町3-6）
} 